\begin{tabular}{|c|c|c|}
\hline stitut & $\begin{array}{l}\text { CARADDE: Jurnal Pengabdian Kepada Masyarakat } \\
\text { https://journal.ilininstitute.com/index.php/caradde } \\
\text { Volume 2 | Nomor 1 | Agustus | 2019 } \\
\text { e-ISSN: } 2621-7910 \text { dan p-ISSN: } 2621-7961 \\
\text { DOI: } \text { https://doi.org/10.31960/caradde.v2i1.263 }\end{array}$ & $\begin{array}{l}\text { GiN } \\
\text { GaradoE }\end{array}$ \\
\hline
\end{tabular}

\title{
Sinema-Konseling untuk Meningkatkan Ketahanan Psikologis Siswa Sekolah Menengah Kejuruan pada Era Digital
}

\author{
Mulawarman $^{1}$, Sigit Haryadi ${ }^{2}$, Eni Rindi Antika ${ }^{3}$, Shania Dea Menany Soputan ${ }^{4}$
}

Keywords :

Sinema-konseling, ketahanan

psikologis, era digital

\section{Corespondensi Author}

Bimbingan dan Konseling, Universitas

Negeri Semarang

Gedung A2 Lantai 1 FIP Universitas

Negeri Semarang, Kampus Sekaran,

Gunungpati, Kota Semarang

Email:mulawarman@mail.unnes.ac.id

\section{History Artikel}

Received: Juli-2019;

Reviewed: Juli -2019

Accepted: Agustus-2019

Published: Agustus-2019

\begin{abstract}
Abstrak. Berbagai tekanan dalam era digital mengharuskan siswa memiliki ketahanan psikologis. Tujuan kegiatan pengabdian kepada masyarakat ini adalah untuk mengembangkan keterampilan konselor/guru BK dalam memberikan layanan kepada siswa sesuai dengan tuntutan perkembangan zaman. Strategi sinema-konseling dilatihkan kepada dua puluh konselor/guru BK Sekolah Menengah Kejuruan di Kabupaten Blora. Pelatihan ini dilaksanakan selama tiga hari yang setara dengan tiga puluh dua jam pelatihan, yaitu pada tanggal 1 sampai 3 Agustus 2019. Instrumen sinema konseling digunakan untuk mengukur keterampilan konselor/guru BK dalam mengaplikasikan strategi sinema-konseling. Hasil pelatihan menunjukkan ratarata keterampilan konselor/guru BK dalam megaplikasikan strategi sinema-konseling mengalami peningkatan. Lebih lanjut konselor/guru BK perlu mempertajam keterampilan dalam mengembangkan pertanyaan reflektif dalam menerapkan strategi sinema-konseling di sekolah.
\end{abstract}

\section{(1) This work is licensed under a Creative Commons Attribution} 4.0 International License

\section{PENDAHULUAN}

Era revolusi industri 4.0 yang disejajarkan dengan era disrupsi dan digitalisasi membawa pengaruh pada perkembangan pendidikan dan siswa sebagai salah satu pihak yang terlibat di dalamnya. Siswa perlu memiliki keterampilan untuk dapat menghadapi berbagai tekanan yang muncul, yaitu hardiness (ketahanan psikologis). Ketahanan psikologis dapat membantu siswa bertahan dari situasi sulit sehingga bermuara pada pemecahan masalah yang baik.

Kobasa dkk. (1982) mendefinisikan hardiness (ketahanan psikologis) sebagai kumpulan karakteristik kepribadian yang berfungsi sebagai sumber pertahanan ketika menghadapi peristiwa hidup yang menekan. Ketahanan psikologis muncul sebagai seperangkat sikap atau kepercayaan mengenai diri dalam berinteraksi dengan dunia di sekitar.
Adanya sikap atau kepercayaan mengenai diri memberikan keberanian dan motivasi untuk melakukan kerja keras demi mengubah situasi yang membuat stres menjadi peluang (Maddi, 2004).

Kobasa (1979) dan Maddi (2002; 2004) menjelaskan bahwa ketahanan psikologis memiliki tiga komponen, yaitu: kontrol, komitmen, dan tantangan. Ketahanan psikologis mendorong siswa memiliki kontrol dan komitmen atas dirinya sendiri sehingga dapat lebih optimis terhadap hal-hal yang menyebabkan stres. Pada akhirnya ketahanan psikologis dapat membantu siswa untuk memandang stres sebagai suatu yang tidak mengancam serta mampu untuk melindungi dirinya dari pengaruh stres yang negatif.

Konselor/guru BK sebagai salah satu pihak yang bertanggungjawab atas kesejahteraan psikologis siswa perlu memberikan layanan sehingga siswa memiliki 
ketahanan psikologis yang baik. Di lain sisi perkembangan pendidikan di era rovolusi industri 4.0 disampaikan perlu adanya selfreform baik dari sisi sumber daya manusia maupun sistem yang berlaku. Penelitian Abdillah (2013) diperoleh hasil bahwa melalui student centered learning siswa diharapkan mampu memiliki kemampuan tanggung jawab belajar secara mandiri dan memilih bahan belajar yang sesuai dengan kebutuhan yang hadapi.

Perkembangan zaman membawa perubahan paradigma konseling, dari metode terapi klinis ke arah terapi pengembangan. Proses konseling tidak lagi berorientasi kepada penyelesaian masalah tetapi lebih kepada pemenuhan tugas perkembangan serta pengembangan potensi konseli (Gysbers \& Henderson, 2001). Mensikapi paradigma di atas, penggunaan teknologi oleh para profesional kesehatan mental secara bertahap meningkat dalam dekade terakhir. Perkembangan cybertherapy, berbagi informasi konseling, pengawasan serta pelatihan konselor terus digalakkan untuk memenuhi ekspektasi masyarakat (Powell, 2008).

Cinema-therapy sebagai salah satu pendekatan konseling menjadi model pemberian bantuan yang dapat digunakan sejalan dengan kedua perubahan paradigma tersebut. Cinema-therapy disampaikan sebagai penggunaan film yang memiliki efek positif pada orang kecuali gangguan psikotik (Solomon, 2001). Film dapat membantu siswa untuk melakukan proses terapi untuk diri sendiri. Hal ini sebagaimana dipahami bahwa film mampu dijadikan sebagai sebuah sarana metafora bagi klien untuk mengembangkan pertumbuhan dan wawasan informasi (Powell \& Newgent, 2010; Sharp, Smith, \& Cole, 2002).

Nola Kortner dalam Eliasa \& Iswanti (2014) menyebutkan bahwa cinema-therapy yang merupakan bagian dari biblio-therapy mampu untuk membantu klien dalam meningkatkan ketahanan emosi dan tekanan mental, pembentukan self-concept dan selfaccepted. Sayangnya di sisi lain hasil penelitian lain diperoleh data bahwa pengaplikasian cinema-therapy dalam pemberian layanan masih sangat minim (Hariyadi, 2015). Dari hasil penelitian tersebut diperoleh diperoleh data $37 \%$ kendala dikarenakan kurangnya pemahaman konselor akan layanan dan 30\% dikarenakan kesalahan prosedur. Terlebih 70\% konselor di lapangan menyatakan bahwa alasan kurangnya waktu layanan menjadi masalah dan $23 \%$ karena minimnya sarana. Tentunya hal ini sangat disayangkan mengingat beberapa nilai tambah dari pendekatan ini.

Merujuk pada paparan di atas maka diperlukan kegiatan pelatihan atau workshop pengembangan kualitas dan kompetensi konselor untuk lebih profesional dalam menjalankan praktik konseling di lapangan. Pelatihan strategi intervensi berbasis kompetensi bagi konselor/guru BK melalui teknik sinema-konseling diharapkan dapat memenuhi harapan konselor lapangan secara praktis dan pengembangan nilai konseptual secara teoritis dalam upaya perbaikan dan peningkatan kualitas pelayanan konseling di sekolah. Selain itu, perubahan pasca pelatihan mampu membantu konselor untuk meningkatkan ketahanan psikologis siswa.

\section{METODE}

Kegiatan pengabdian kepada masyarakat ini dilaksanakan dalam tiga tahap, yaitu: identifikasi peserta pelatihan, pelaksanaan pelatihan, dan evaluasi hasil pelatihan. Tahap identifikasi peserta dilakukan dengan memilih konselor/guru BK yang kurang memiliki keterampilan dalam memberikan strategi sinema-konseling.

Pelatihan dilaksanakan selama tiga hari tatap muka yang setara dengan 32 jam pelatihan. Pelatihan dilaksanakan di SMK Negeri 1 Blora sebagai tuan rumah kegiatan. Peserta pelatihan terdiri dari 20 konselor/guru BK SMK di Kabupaten Blora.

Kegiatan ekspositori, tanya jawab dan diskusi mengawali tahap pelaksanaan dalam kegiatan pelatihan. Setelah peserta memahami konsep, kegiatan dilanjutkan dengan praktik peer counseling/peer teaching tersupervisi. Pelatihan kemudian diakhiri dengan kegiatan evaluasi hasil pelaksanaan strategi sinemakonseling.

Indikator yang digunakan untuk mengevaluasi keberhasilan pelatihan ini meliputi: (1) ketepatan dalam melaksanakan strategi sinema-konseling, (2) hasil peer observasi dari sesama praktikkan (konselor/guru BK) lain yang melaksanakan pelatihan sesuai indikator layanan, dan (3) 
hasil analisis dan evaluasi dari layanan sinema-konseling oleh pelatih sesuai indikator layanan.

Selain penilaian dalam proses peer counseling, keterampilan konselor/guru BK dalam memberikan layanan sinema-konseling juga diukur menggunakan instrumen sinemakonseling. Instrumen ini terdiri dari 10 aitem pernyataan dalam bentuk skala Guttman. Instrumen ini digunakan untuk mengukur keterampilan konselor/guru BK sebelum (pretest) mendapatkan pelatihan dan setelah (posttest) mendapatkan pelatihan sinema-konseling.

\section{HASIL DAN PEMBAHASAN}

Secara umum diperoleh hasil bahwa kegiatan pengabdian kepada masyarakat melalui pelatihan ini dapat meningkatkan keterampilan konselor/guru BK dalam mengaplikasikan strategi sinema-konseling. Perbandingan hasil pre-test dan post-test peserta pelatihan lebih lanjut digambarkan dalam tabel 1.

Tabel 1. Perbandingan Hasil Pre-Test dan Post-Test

\begin{tabular}{cc|c|}
\hline $\begin{array}{c}\text { Rerata } \text { Pre- } \\
\text { test }\end{array}$ & $\begin{array}{c}\text { Rerata Post- } \\
\text { test }\end{array}$ & Margin Skor \\
\hline 6,3 & 7,45 & 1,15 \\
\hline
\end{tabular}

Merujuk pada tabel 1, dapat dilihat bahwa terjadi peningkatan keterampilan peserta sebelum mendapatkan pelatihan dan setelah mendapatkan pelatihan dengan margin skor sebesar 1,15. Peningkatan keterampilan diikuti dengan peningkatan pemahaman atas konsep sinema-konseling dan ketahanan psikologis siswa. Lebih lanjut perbandingan hasil pre-test dan post-test peserta pelatihan dapat dilihat dalam gambar 1 .

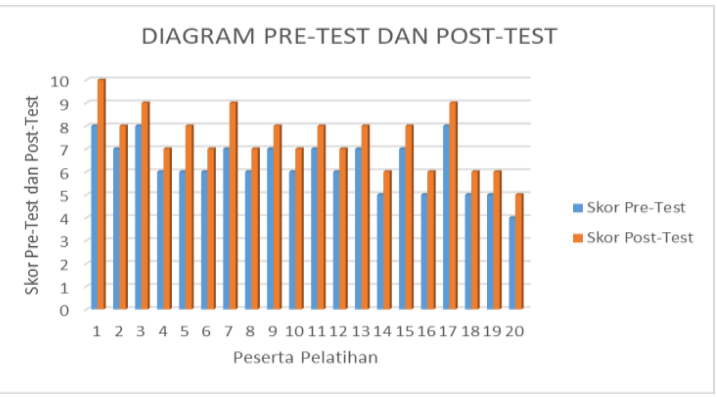

Gambar 1. Diagram Perbedaan Hasil Pre-test dan Post-test
Selain merujuk pada hasil pre-test dan post-test sebagaimana dijelaskan pada tabel 1 dan gambar 1 , evaluasi hasil capaian pelatihan juga didasarkan pada kegiatan peercounseling/peer teaching tersupervisi melalui lembar observasi. Laporan hasil praktik sinema-konseling di sekolah sebagai tugas mandiri juga menjadi salah satu bahan evaluasi keberhasilan kegiatan pelatihan.

Pada sesi ekspositori dan diskusi, peserta nampak antusias karena beberapa peserta mengaku baru pertama kali mengenal sinemakonseling. Meskipun hampir seluruh konselor/guru BK yang menjadi peserta pelatihan telah melaksanakan layanan konseling, strategi yang diaplikasikan selama ini masih bersifat konvensional. Sementara itu, di lain sisi perkembangan zaman mengharuskan konselor/guru BK untuk terus berinovasi dan mengembangkan kreativitas mereka dalam memberikan layanan yang efektif dan efisien sesuai dengan kebutuhan siswa. Pelaksanaan sesi ekpositori dan diskusi didokumentasikan pada gambar 2 .

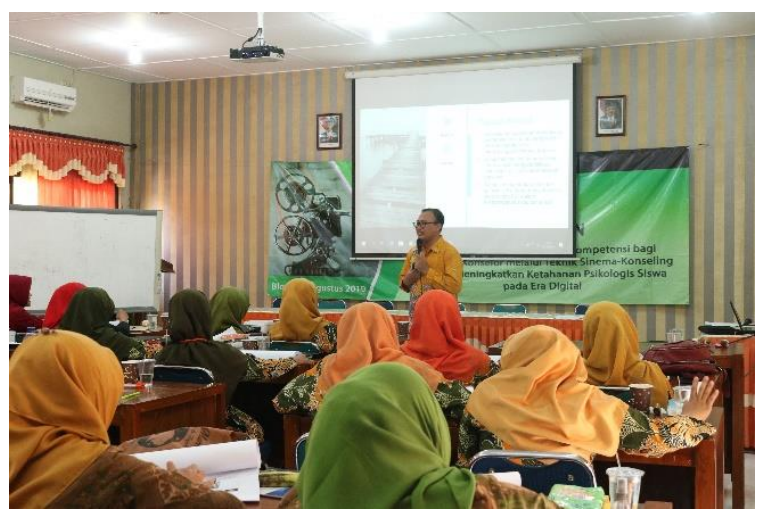

Gambar 2. Kegiatan Ekspositori, Tanya Jawab, dan Diskusi

Antusiasme peserta dalam menghadapi perkembangan ilmu senada dengan nilai novelty atau kebaruan dalam pemberian layanan. Hal ini dimaknai sebagai daya tarik bagi peserta pelatihan yang akan berperan sebagai pelaksana strategi sinema-konseling dan juga menggugah minat siswa sebagai penerima layanan. Selain itu, era digital dapat diibartkan seperti dua sisi mata uang, yaitu membawa dampak positif dan dampak negatif (Prabawa, 2018). Apabila dampak negatif ini tidak dapat diantisipasi dan dikelola dengan baik, maka akan memicu munculnya berbagai tekanan sehingga menimbulkan stres. Oleh karena itu, konselor/guru BK perlu 
Caradde: Jurnal Pengabdian Kepada Masyarakat

Vol 2 No 1, Agustus 2019

memahami konsep tentang ketahanan psikologis siswa dan memiliki keterampilan mengaplikasikan strategi intervensi untuk meningkatkannya.

Pelaksanaan pelatihan menggunakan metode peer counseling/peer teaching tersupervisi sebagaimana dapat dilihat pada gambar 3 . Melalui pendekatan ini, peserta pelatihan dapat mencapai penguasaan konsep dan keterampilan dalam menelaah dan mengkaji lebih lanjut strategi sinema-konseling. Hal ini sesuai dengan hasil penelitian yang dilakukan oleh Muslikah, Hariyadi, dan Amin (2016) yang membuktikan bahwa konsep peer terbukti efektif dalam rangka pembelajaran konseling dan meningkatkan kemampuan peserta latih dalam pengembangan kompetensi konseling yang dimiliki. Selain itu, Falcchiko \& Goldfinch (2000) menyatakan bahwa metode peer memiliki hasil yang cukup efekitf bahkan tidak jauh berbeda dengan penilaian yang dilakukan oleh pengajar. Senada dengan dua penelitian di atas, Antika (2017) dalam penelitiannya membuktikan bahwa strategi peer supervision dapat meningkatkan tujuan pembelajaran.

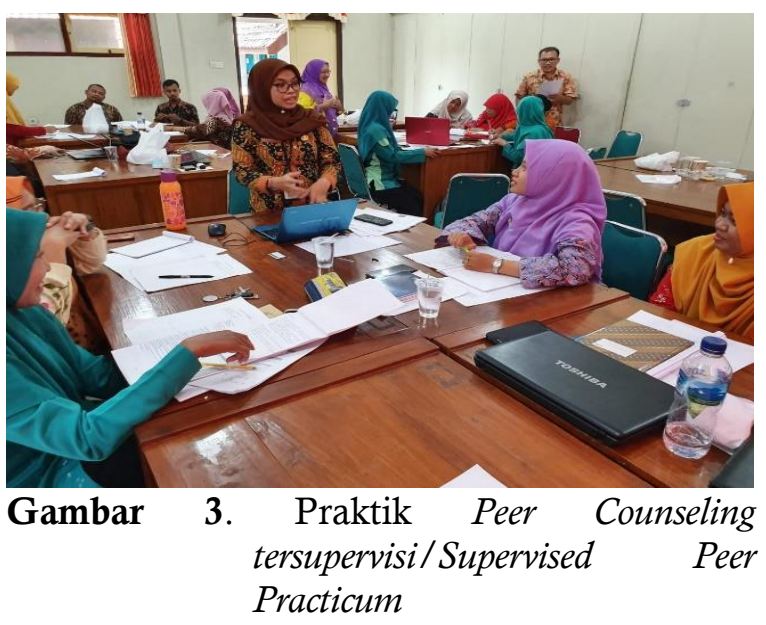

Berdasarkan pada tabel 1 dan gambar 1 dapat dilihat pada kondisi awal pelatihan menunjukkan bahwa tingkat keterampilan konselor/guru BK dalam mengaplikasikan strategi sinema-konseling masih relatif rendah. Hasil tersebut dapat dimaknai bahwa pelaksanaan strategi sinema-konseling di sekolah belum dilakukan secara optimal. Adapun hasil post-test menunjukkan adanya peningkatan rerata skor dengan margin sebesar 1,15 . Artinya, telah tejadi peningkatan sebagai awal perubahan yang terjadi pada diri peserta.
Pengalaman dan keterampilan baru yang didapatkan oleh peserta diharapkan mampu menjadi pemicu meningkatknya kompetensi konselor dalam mengembangkan strategi intervensi yang kreatif dan inovatif. Kompetensi konselor yang memadai sangat diperlukan untuk memberikan layanan konseling yang efektif dan efisien di era disruptif sesuai dengan kebutuhan siswa. Secara lebih spesifik dalam hal ini adalah keterampilan konselor dalam mengaplikasikan strategi sinema-konseling untuk meningkatkan ketahanan psikologi siswa di era digital. Lebih lanjut konselor/guru BK perlu mempertajam keterampilan untuk mengembangkan pertanyaan reflektif dalam menerapkan strategi sinema-konseling di sekolah.

Bersamaan dengan evaluasi capaian pelatihan, juga dilakukan evaluasi terhadap kegiatan pelatihan secara keseluruhan. Secara umum peserta pelatihan memberi balikan yang positif, kegiatan dinilai sangat menyenangkan, fasilitator kreatif untuk mengembangkan suasana belajar yang kondusif, dan supervisor juga memberikan pendampingan secara intens selama praktik dilaksanakan. Peserta berharap agar kegiatan serupa dilaksanakan secara rutin dan terjadwal dengan topik-topik lain sehingga mereka dapat terus mengikuti perkembangan ilmu.

\section{SIMPULAN DAN SARAN}

Simpulan yang diperoleh dari pelaksanaan program pengabdian kepada masyarakat dalam kegiatan pelatihan strategi intervensi berbasis kompetensi bagi konselor/guru BK melalui teknik sinemakonseling untuk meningkatkan ketahanan psikologis siswa di era digital adalah berhasil sesuai dengan yang telah direncanakan. Adapun keberhasilan yang dimaksud meliputi perizinan internal lembaga, prizinan dan koordinasi dengan dinas dan MGBK SMK Kota Salatiga, kegiatan pelatihan, dan kegiatan praktik di sekolah. Capaian hasil pelatihan dapat dilihat dari meningkatnya keterampilan konselor/guru BK dalam mengaplikasikan strategi sinema konseling.

Kegiatan pengabdian kepada masyarakat masih sangat dinantikan oleh konselor/guru BK di Kabupaten Blora. Kegiatan pelatihan serupa diharapkan dapat dilaksanakan secara berkelanjutan sehingga 
konselor/guru BK berkesempatan untuk terus update pengetahuan dan keterampilan, sehingga mampu mengembangkan diri. Pada akhirnya, pengembangan diri konselor/guru BK secara berkelanjutan akan bermuara pada pelaksanaan layanan yang efektif dan efisien.

\section{DAFTAR RUJUKAN}

Abdillah, L. A. (2013). Students learning center strategy based on e-learning and blogs. ArXiv Preprint ArXiv:1307.7202.

Antika, E. R. (2017). Internalisasi Mind Skills Mahasiswa BK dalam Praktik Keterampilan Dasar Komunikasi melalui Strategi Supervisi Terbimbing. Tesis tidak diterbitkan. Malang: Pascasarjana BK UM.

Eliasa, E. I., \& Iswanti, S. (2014). Bibliotherapy with the Career Topic to Increase the Student's Career Motivation of Guidance and Counseling. ProcediaSocial and Behavioral Sciences, 114, 434438.

Gysbers, N. C., \& Henderson, P. (2001). Comprehensive guidance and counseling programs: A rich history and a bright future. Professional School Counseling, 4(4), 246-256.

Kobasa, dkk. (1982). Hardiness and health: A prospective study. Journal Personality and Social Psychology, 168-177.

Kobasa, S. C. (1979). Stresful Life events, personality, and health: An inquiry into hardiness. Journal of Personality and Social Psychology, 1-11.

Maddi, S. R. (2002). The Story of hardiness: Twenty years of theorizing, research, and practice. Consulting Psychology Journal: Practice and Research, 175-178.
Maddi, S. R. (2004). Hardiness: An operationalization of existential courage. Journal of Humanistic Psychology, 279-298.

Muslikah, Hariyadi, S., \& Amin, Z.N. (2016). Pengembangan Model Peer Counseling Sebagai Media Pengalaman Praktik Konseling. Indonesian Jornal of Guidance and Counseling, 5(3), 48-52.

Powell, M. L. (2008). Cinematherapy as a clinical intervention: Theoretical rationale and empirical credibility. Dissertation Abstracts International Section A: Humanities and Social Sciences (Vol. 69). University of Arkansas.

Powell, M. L., \& Newgent, R. A. (2010). Improving the Empirical Credibility of Cinematherapy. Counseling Outcome Research and Evaluation, 1(2), 40-49. https://doi.org/10.1177/215013781037 3920

Prabawa, A. F. (2018). Peran Lingkungan Membentuk Generasi Rahmatan Lil Alamin. Malang: LPI Sabilillah Malang.

Sharp, C., Smith, J. V., \& Cole, A. (2002). Cinematherapy: Metaphorically promoting therapeutic change. Counselling Psychology Quarterly. https://doi.org/10.1080/095150702101 40221

Solomon, G. (2001). Reel therapy: How movies inspire you to overcome life's problems. BookBaby. 